\title{
Analisis tentang Laporan Pajak Terutang terhadap Perdagangan Online (E- Commerce)
}

\author{
Grace Angeline Sihombing \\ Universitas Indonesia \\ graceangelines@gmail.com
}

\begin{abstract}
Abstrak. Dalam satu dekade ini, telah terjadi perkembangan signifikan dalam dunia ekonomi sebagai salah satu dampak perkembangan teknologi yang sangat cepat. Salah satu perubahan yang terjadi adalah beralihnya perdagangan dari cara konvensional, dimana terjadi pertemuan snatara pembeli dengan penjual secara langsung atau tatap muka, ke perdagangan daring/ online. Dalam perdagangan online, pembeli dan penjual „bertemu“ di dunia maya dengan wadah jual-eli berupa website dan/atau aplikasi. Perjanjian dan kesepakatan penjualan tercipta tidak lagi berdasarkan perjanjian tertulis, tapi terjadi melalui kesepakatan pemesanan. Namun perubahan perdagangan ini tidak merubah fakta bahwa pada setiap transaksi tetap melekat kewajiban pembayaran pajak. Dalam hal pengenaan pajak, perdagangan online dapat dikenakan pajak penghasilan karena jika berdasaran syarat subjektif (pedagang) dan syarat objektif (penghasilan), pedagang dalam perdagangan online telah memenuhi syarat pengenaan pajak penghasilan. Undang-undang Pajak Penghasilan dirasa belum cukup mampu memberikan arahan mengenai pengenaan pajak terhadap perdagangan online, sehingga dikhawatirkan, pengenaan pajak penghasilan terhadap perdagangan online menjadi kurang maksimal. Dengan demikian diperlukan adanya aturan baru untuk dijadikan dasarhukum pengenaan pajak terhadap perdagangan online.
\end{abstract}

Kata Kunci: Pajak, Perdagangan Online, Kepastian Hukum 


\section{PENDAHULUAN}

Salah satu dari empat tujuan negara Indonesia sebagaimana ditetapkan dalam Pembukaan Undang-Undang Dasar Republik lndonesia Tahun 1945 (UUD NRI 1945) Alinea IV, adalah untuk memajukan kesejahteraan umum. Kesejahteraan umum ini dapat diartikan sebagai perwujudan dari perekonomian yang baik dan kuat sehingga bisa mensejahterakan masyarakat Indonesia. Hal ini dapat dicapai melalui programprogram pemerintah yang tentunya memerlukan dana dari pendapatan negara. Sumber pendapatan negara ini sangat penting untuk melakukan kegiatan di setiap tingkat pemerintahan, karena tanpa pendapatan yang memadai program pemerintah tidak akan berjalan secara optimal.

Yang dimaksud dengan penerimaan negara atau penerimaan uang negara atau pendapatan pemerintah yang mencakup pajak, retribusi, laba perusahaan negara, denda, kontribusi masyarakat, dan lain sebagainya.Pajak merupakan salah satu sumber penerimaan negara yang memiliki peran penting dalam menopang pembiayaan pembangunan dan menggambarkan kemandirian ekonomi. Pajak mempunyai peranan yang sangat penting dalam kehidupan bernegara, khususnya di dalam pelaksanaan pembangunan karena pajak merupakan sumber pendapatan negara untuk membiayai semua pengeluaran termasuk pengeluaran pembangunan.

Pajak dan pengeluaran pemerintah memainkan peran penting dalam mendukung dan menstabilkan perekonomian nasional. Pajak dan pengeluaran pemerintah akan mempengaruhi lapangan kerja dan tingkat permintaan agregat pertumbuhan ekonomi.5 Pajak yang diterima oleh pemerintah akan digunakan untuk membiayai berbagai kegiatan pemerintah. Di negara maju, pajak adalah sumber utama pendapatan pemerintah, bagian dari pengeluaran pemerintah adalah untuk membiayai administrasi pemerintah dan sebagian untuk membiayai kegiatan pembangunan. Membayar gaji untuk pegawai pemerintah, membiayai sistem pendidikan dan kesehatan masyarakat, membiayai pengeluaran untuk angkatan bersenjata, dan membiayai berbagai jenis infrastruktur penting yang akan didanai oleh pemerintah. Pengeluaran ini akan meningkatkan aktivitas ekonomi negara.

Ada berbagai macam pajak yang menjadi penerimaan negara, salah satu jenis pajak yang dipungut oleh pemerintah adalah pajak penghasilan. Pajak penghasilan merupakan pajak atas setiap tambahan kemampuan ekonomis yang diperoleh wajib pajak. Tentulah termasuk laba dari berbagai jenis usaha perdagangan barang atau jasa.

Dunia usaha di zaman sekarang dapat dilakukan baik secara langsung atau menggunakan media komputer yang saling terhubung yang disebut dengan Internet. Karena didukung oleh sebuah jaringan internet sehingga para pelaku bisnis dapat menjual dan menawarkan jasa melalui online. Internet merupakan jaringan komputer terbesar di dunia padasaat ini digunakan oleh berjuta-juta orang yang tersebar di dunia.

Dewasa ini, bisnis dan perdagangan sudah banyak beralih dari bentuk konvensional dimana penjual dan pembeli berra langsung secara fisik ke perdagangan daring (online) melalui e-commerce. Berkembangnya perdagangan secara online (online shop) didasarkan atas kemudahan bagi pelaku bisnis dalam mempromosikan barangnya serta tidak memerlukan biaya yang lebih karena tidak memerlukan adanya toko secara fisik. Melihat sistematik kerja yang minim untuk biaya operasional namun dapat menghasilkan omset atau penghasilan yang diperoleh pengusaha toko online sama bahkan bisa melebihi pedagang konvensional karena perdagangan online memiliki jumlah pasar yang tanpa dibatasi oleh ruang dan waktu.

Hal inilah yang menjadikan pengusaha dalam perdagangan online (e-commerce) sudah sepantasnya dijaring secara maksimal dalam pemenuhan kewajiban pajak untuk menambah pendapatan negara dalam menunjang kesejahtraan rakyat dan pembangunan nasional.

Ada banyak definisi untuk $E$ Commerce, tapi yang pasti E-Commerce merujuk pada semua bentuk transaksi 
komersial yang menyangkut organisasi dan individu yang didasarkan pada proses dan transmisi data yang digitalisasikan, termasuk teks, suara dan gambar. Termasuk juga pengaruh bahwa pertukaran informasi komersial secara elektronik yang mungkin terjadi antara institusi pendukungnya dan aktivitas komersial pemerintah. Ini termasuk antara lain manajemen organisasi, negosiasi dan kontrak komersial, legal dan kerangka regulasi, penyusunan perjanjian keuangan, dan pajak satu sama lain. Electronic Commerce (Perniagaan Elektronik), sebagai bagian dari Electronic Business (bisnis yang dilakukan dengan menggunakan electronic transmission), oleh para ahli dan pelaku bisnis dicoba dirumuskan definisinya. Secara umum E-Commerce dapat didefinisikan sebagai segala bentuk transaksi perdagangan atau perniagaan barang dan jasa (trade of goods and service) dengan menggunakan media elektronik. Jelas, selain dari yang telah disebutkan di atas, bahwakegiatan perniagaan tersebut merupakan bagian dari kegiatan bisnis.

Berbeda dengan transaksi perdagangan biasa pada umumnya, transaksi E-Commerce memiliki beberapa karakteristik yang sangat khusus sehingga mengakibatkan implikasi pajak yang agak rumit dari kegiatan tersebut. Hal ini terjadi karena transaksi elektronik antara $e$ - merchant (pihak yang menawarkan barang atau jasa melalui internet) dengan e-customer, (pihak yang membeli barang atau jasa melalui internet) yang terjadi di dunia maya atau di internet pada umumnya berlangsung secara paperless transaction, sedangkan dokumen yang digunakan dalam transaksi tersebut bukanlah paper document, melainkan dokumen elektronik (digital document).

Meski pasar E-Commerce berkembang pesat di Indonesia namun baru segelintir pelaku E-Commerce yang sudah memiliki Nomor Pokok Wajib Pajak (NPWP). Menurut data yang diperoleh dari Direktorat Jenderal Pajak ada 1.600 (seribu enam ratus) sampling (pelaku E-Commerce) yang dicoba, dari jumlah itu ada 600 (enam ratus) yang belum teridentifikasikan dan 1.000 (seribu) sudah teridentifikasikan. Dari 1.000 (seribu) pelaku usaha baru 620 (enam ratus dua puluh) yang sudah memiliki Nomor Pokok Wajib Pajak (NPWP). Dari yang sudah memiliki Nomor Pokok Wajib Pajak (NPWP) itu sebagian besar sudah melapor tapi tidak diketahui dilaporkannya itu sudah sesuai fakta yang terjadi pada saat bertransaksi.

Menurut data yang ada di Direktorat Jenderal Pajak, nilai pasar dari suatu transaksi E- Commerce di Indonesia sudah mencapai Rp 96.000.000.000.000.00 (sembilan puluh enam triliun rupiah) pada tahun 2015 dan akan meningkat sampai Rp 288.000.000.000.000.00 (dua ratus delapan puluh delapan triliun rupiah) di tahun 2016 ini. Sejak tahun 2012, Direktorat Jenderal Pajak sudah melakukan kajian tentang $E$ Commerce. Pertama terhadap aspek-aspek perpajakan yang ada, sehingga mendapatkan apa yang harus dilakukan terhadap perkembangan dunia E-Commerce ini. Kedua membentuk tim di Direktorat Jenderal Pajak yang terdiri dari tim untuk memutuskan peraturan-peraturan atau tatacara aspek perpajakannya, kemudian tentang pengelolaan, penggalian potensi pajaknya.

Direktorat Jenderal Pajak mengeluarkan Surat Edaran-62/PJ/2013 dikeluarkan pada bulan desember 2013 (tentang Penegasan Ketentuan Perpajakan atas Transaksi E-Commerce) yang diharapkan agar bisa menjadi penegasan bahwa ketentuan perpajakan terkait dengan transaksi atas $E$ Commerce itu sama ketentuannya mulai dari mendaftar, menghitung, membayar, melapor, itu juga berlaku bagi setiap pelaku usaha yang melakukan kegiatan $e$-Commerce ini.

Dari uraian latar belakang diatas, maka perumusan masalah dalam penelitian ini adalahsebagai berikut:

1. Bagaimana peraturan perundangundangan mengatur tentang pajak atas transaksi E-Commerce?

2. Bagaimana laporan terhadap pajak terutang atas transaksi E-Commerce dalam rangka kepastian hukum?

\section{METODE PENELITIAN}

Tipe penelitian hukum yang 
digunakan dalam menyelesaikan tugas ini adalah yuridis normatif. Penelitian hukum dalam Bahasa Inggris disebut Legal Research atau dalam Bahasa Belanda rechtsonderzoek. Penelitian hukum dilakukan untuk mencari pemecahan atas isu hukum yang timbul, yaitu memberikan preskripsi mengenai apa yang seyogyanya atas isu yang diajukan. Penelitian hukum sendiri dilakukan untuk menemukan bahan hukum autoritatif mengenai isu hukum tertentu. Peter Mahmud Marzuki mendefinisikan penelitian hukum sebagai suatu proses untuk menemukan aturan hukum, maupun doktrin-doktrin hukum guna menghadapi isu hukum yang dihadapinya, sehingga dalam rangka penelitian ini, Penulis memilih menggunakan tipe penelitian yuridis normatif dengan bersumber pada bahan-bahan kepustakaan.

\section{PEMBAHASAN}

\section{Pengaturan terhadap Pajak Atas Transaksi E-Commerce di Indonesia}

Berdasarkan SE-62/PJ/2013 telah mempertegas bahwa tidak ada pajak baru dalam transaksi E-Commerce sehingga tidak ada perbedaan dalam penerapan peraturan perundang- undangan perpajakan antara transaksi E-Commerce ataupun konvensional. Oleh karena itu bagi penjual atau pembeli dapat dikenakan pajak sesuai ketentuan perundang-undangan perpajakan yang sudah ada.

Pajak atas transaksi E-Commerce bertujuan untuk menerapkan keadilan bagi semua wajib pajak baik konvensional maupun E-Commerce. Karena pada dasarnya kewajiban wajib pajak pelaku bisnis konvensional atau E-Commerce tidak berbeda.

$\begin{array}{rcr} & \text { Kegagalan dalam memungut pajak } \\ \text { dari transaksi } & \text { E-Commerce akan }\end{array}$
mengakibatkan tidak dilaksanakannya prinsip keadilan dan kepastian dalam penegakan hukum, mengakibatkan ketidakseimbangan dalam persaingan antara pengusaha karena beban pajak yang tidak merata di antara wajib pajak tersebut, serta penerimaan negara dari pajak yang tidak maksimal.

Pajak atas transaksi E-Commerce sama dengan transaksi biasa sesuai dengan penjelasan pada Pasal 11 ayat (1) UndangUndang Pajak Pertambahan Nilai diatur bahwa "Pemungutan Pajak Pertambahan Nilai dan Pajak Penjualan atas Barang Mewah menganut prinsip akrual, artinya terutangnya pajak terjadi pada saat penyerahan Barang Kena Pajak atau pada saat penyerahan Jasa Kena Pajak, meskipun pembayaran atas penyerahan tersebut belum diterima atau belum sepenuhnya diterima, atau pada saat impor Barang Kena Pajak. Saat terutangnya pajak untuk transaksi yang dilakukan melalui E-Commerce tunduk pada ayat ini.

Sebagaimana dijelaskan di dalam penegasan peraturan perpajakan SE62/PJ/2013 atas E-Commerce, Perkembangan teknologi informasi dan komunikasi telah menyebabkan transformasi model dan strategi bisnis yang perlu ditegaskan aspek perpajakannya. Pada prinsipnya, transaksi perdagangan barang dan/atau jasa melalui sistem elektronik, yang selanjutnya disebut $E$ Commerce sama dengan transaksi perdagangan barang dan/atau jasa lainnya, tetapi berbeda dalam hal cara atau alat yang digunakan. Oleh karena itu, tidak ada perbedaan perlakuan perpajakan antara transaksi E-Commerce dan transaksi perdagangan barang dan/atau jasa lainnya.

Dalam Surat Edaran Direktorat Jenderal Pajak ini diberikan penegasan mengenai aspek Ketentuan Umum dan Tata Cara Perpajakan, Pajak Penghasilan, dan Pajak Pertambahan Nilai dan Pajak Penjualan atas Barang Mewah atas transaksi $E$ Commerce.

Subjek Pajak akan dikenakan pajak apabila menerima atau memperoleh penghasilan. Dasar hukum Pajak Penghasilan adalah Undang-Undang Nomor 7 Tahun 1984 tentang Pajak Penghasilan (PPh) sebagaimana telah diubah dengan Undang-Undang Nomor 36 tahun 2008. Undang-Undang ini mengatur pengenaan pajak terhadap subjek pajak berkenaan dengan penghasilan yang diterima atau diperolehnya dalam tahun pajak.

Sebagaimana yang telah dijelaskan, terdapat tiga asas pemungutan pajak yaitu, Asas Domisili atau Asas Tempat Tinggal, 
dimana negara berhak mengenakan pajak atas seluruh penghasilan wajib pajak yang bertempat tinggal di wilayahnya, baik penghasilan yang berasal dari dalam maupun luar negri, dan asas ini berlaku untuk wajib pajak dalam negeri. Asas Sumber, dimana negara berhak mengenakan pajak atas penghasilan yang bersumber di wilayahnya tanpa memperhatikan tempat tinggal wajib pajak. Asas Kebangsaan, dimana pengenaan pajak dihubungkan dengan kebangsaan suatu negara.

Bentuk Usaha Tetap menurut Pasal 2 ayat (5) Undang-Undang Pajak Penghasilan yaitu Bentuk Usaha Tetap adalah bentuk usaha yang dipergunakan oleh orang pribadi yang tidak bertempat tinggal di Indonesia, orang pribadi yang berada di Indonesia tidak lebih dari 183 (seratus delapan puluh tiga) hari dalam jangka waktu 12 (dua belas) bulan, dan badan yang tidak didirikan dan tidak bertempat kedudukan di Indonesia untuk menjalankan usaha atau melakukan kegiatan di Indonesia, yang dapat berupa, Tempat kedudukan manajemen, Cabang perusahaan, Kantor perwakilan, Gedung kantor, Pabrik, Bengkel, Gudang, Ruang untuk promosi dan penjualan, Pertambangan dan penggalian sumber alam, Wilayah kerja pertambangan minyak dan gas bumi, Perikanan, peternakan, pertanian, perkebunan, atau kehutanan.

Implikasi pajak untuk E-Commerce akan timbul apabila penyewa atas space di Internet Service Provider atau penyedia jasa Internet adalah perusahaan yang berdomisili di luar negeri. ${ }^{14}$ Bahwa semua transaksi yang terkait dengan persiapan untuk mengoperasikan website, terhadap server dimiliki oleh wajib pajak luar negeri, perlakuannya akan sama dengan yang telah dijelaskan di atas. Misalnya salah satu penyewa website, yang merupakan wajib pajak luar negeri, menggunakan website tersebut untuk menyimpan informasi tertentu, yang kemudian ditawarkan ke pihak ketiga, sehingga pihak ketiga menjadi pelanggannya, dan pelanggan tersebut membayar iuran untuk mengakses informasi yang dimaksud, akan dimasukkan dalam kategori royalty sesuai dengan penjelasan Pasal 4 ayat (1) huruf (h)
Undang-Undang Pajak Penghasilan. Sehingga apabila pelanggannya wajib pajak Indonesia, maka penyewa website harus dipotong Pajak Penghasilan Pasal 26.

Pajak Pertambahan Nilai (PPN) adalah pajak yang dikenakan terhadap penyerahan atas impor Barang Kena Pajak (BKP) atau Jasa Kena Pajak (JKP) yang dilakukan oleh Pengusaha Kena Pajak, dan dapat dikenakan berkali-kali setiap ada pertambahan nilai dan dapat dikreditkan. Dasar hukum Pajak Pertambahan Nilai adalah Undang-Undang Nomor 8 Tahun 1983 tentang Pajak Pertambahan Nilai dan atau Penjualan atas Barang Mewah sebagaimana telah diubah dengan Undang-Undang Nomor 42 Tahun 2009.

Seperti yang tertera dalam Pasal 11 ayat (1) Undang-Undang Nomor 8 Tahun 1983 sebagaimana yang telah diubah dalam Undang-Undang Nomor 42 Tahun 2009, terutangnya pajak terjadi pada saat, Penyerahan Barang Kena Pajak, Impor Barang Kena Pajak, Penyerahan Jasa Kena Pajak, Pemanfaatan Barang Kena Pajak Tidak Berwujud dari Luar Daerah Pabean, Pemanfaatan Jasa Kena Pajak dari Luar Daerah Pabean, Ekspor Barang Kena Pajak Berwujud, Ekspor Barang Kena Pajak Tidak Berwujud, Ekspor Jasa Kena Pajak.

Pajak Pertambahan Nilai menurut Pasal 12 Undang-Undang Nomor 42 Tahun 2009 yaitu, Pengusaha Kena Pajak terutang pajak di tempat tinggal atau tempat kedudukan dan tempat kegiatan usaha dilakukan atau tempat lain yang ditetapkan oleh Direktorat Jenderal Pajak, Atas pemberitahuan secara tertulis dari Pengusaha Kena Pajak, Direktorat Jenderal Pajak dapat menetapkan satu tempat atau lebih sebagai tempat pajak terutang, Dalam hal impor, terutangnya pajak terjadi di tempat Barang Kena Pajak dimasukkan.

Pemungutannya dilakukan oleh Direktorat Jenderal Bea dan Cukai, Orang pribadi atau badan yang memanfaatkan Barang Kena Pajak Tidak Berwujud dan/atau Jasa Kena Pajak yang berasal dari luar daerah Pabean di dalam daerah Pabean, terutang pajak di tempat tinggal atau tempat 
kedudukan dan/atau tempat kegiatan usaha. Hal tersebut senada dengan Organisation for Economic Co-operation and Development (OECD) yang merekomendasikan tempat terutang dari Pajak Pertambahan Nilai dan Pajak Penjualan atas Barang Mewah, yaitu dimana konsumsi atas barang/jasa terjadi, dalam Pasal 1 dari empat model perpajakan untuk transaksi $E$ Commerce yaitu perpajakan atas perdagangan lintas batas harus di bawah jurisdiksi dimana konsumsi dilakukan.

Prinsip-prinsip perpajakan atas ECommerce adalah Neutrality, Perpajakan seharusnya menjadi netral dan adil dalam membedakan antara bentuk transaksi $E$ Commerce dengan bentuk transaksi konvensional. Keputusan bisnis seharusnya dimotivasi oleh keadaan ekonomi dibandingkan dengan pertimbangan pajak. Wajib pajak dalam situasi dan transaksi yang sama seharusnya menjadi subjek yang sama pula dalam level perpajakan. Efficiency, Compliance cost untuk Wajib Pajak dan Administrative cost bagi pejabat pajak seharusnya dapat diminimalkan sejauh mungkin.

Certainty and Simplicity, peraturan perpajakan harus jelas dan mudah untuk dimengerti, jadi Wajib Pajak dapat mengantisipasi konsekuensi-konsekuensi pajak sebelum terjadi transaksi, termasuk mengetahui kapan, dimana dan bagaimana pajaknya terhitung. Effectiveness and Fairness, Perpajakan harus menghasilkan jumlah yang tepat dari pajak itu sendiri, sehingga harus dapat meminimalisir potensi penghindaran pajak (tax avoidance) dan penggelapan pajak (tax evasion) dengan tetap mengukur resiko yang dapat terjadi. Flexibility, Sistem perpajakan seharusnya bersifat fleksibel dan dinamis untuk memastikan mereka sejalan dengan teknologi dan perkembangan komersial. Jadi tidak ada untuk membebaskan E-Commerce dari pajak. Besarnya pajak akan dikenakan pada transaksi dengan media elektronik adalah sebanyak yang dapat dikenakan pajak dengan media fisik.

Dengan adanya prinsip-prinsip perpajakan ini, maka hakikat berlakunya aturan-aturan hukum ini tidak terlepas dari hukum yang berlaku karena penetapan penguasa negara, dan hukum yang tidak tergantung dari pandangan manusia tentang baik buruknya, hukum yang asli. ${ }^{18}$ Bahwa segala kejadian di alam ini diperintah dan dikemudikan oleh suatu undang- undang abadi yang menjadi dasar kekuasaan dari semua peraturan-peraturan lainnya.

Terdapat 4 macam golongan hukum (rechtscategorien), yaitu lex aeterna, lex naturalis, lex divina, hukum positif. Lex Aeterna (Hukum Abadi), yaitu rasio Tuhan sendiri yang

mengatur segala hal yang ada sesuai dengan tujuan dan sifatnya, karena itu merupakan sumber dari segala hukum, Lex Divina (Hukum Ke-Tuhanan), yaitu sebagian kecil dari rasio Tuhan yang diwahyukan kepada manusia, Lex Naturalis (Hukum Alam), yaitu bagian dari Lex Divina yng dapat ditangkap oleh rasio manusia atau merupakan penjelmaan dari Lex Aeterna di dalam rasio manusia berkat rasio manusia, dan Hukum Positif, yaitu hukum yang berlaku sungguh- sungguh di dalam masyarakat.

\section{Laporan Pajak Terutang Atas Transaksi E-Commerce Dalam Rangka Kepastian Hukum}

Hukum merupakan sebuah sistem norma yang menekankan aspek "seharusnya" atau dassollen, dengan menyertakan beberapa peraturan tentang apa yang harus dilakukan. Norma- norma merupakan produk dan aksi manusia yang deliberatif. Undang-undang yang berisi aturan-aturan yang bersifat umum menjadi pedoman bagi individu bertingkah laku dalam bermasyarakat, baik dalam hubungan dengan sesama individu maupun dalam hubungannya dengan masyarakat. Aturan-aturan itu menjadi batasan bagi masyarakat dalam membebani atau melakukan tindakan terhadap individu. Adanya aturan itu dan pelaksanaan aturan tersebutmenimbulkan kepastian hukum.

Selain kepastian hukum, hukum pajak juga memiliki berbagai fungsi yang berdasarkan kepada azas-azas yang bertujuan utama menyejahterakan penduduknya. Fungsi 
yang pertama dalam hukum pajak yaitu sebagai acuan dalam menciptakan sistem pemungutan pajak yang harus memenuhi syarat kepastian, efisien, dan sederhana sejelas-jelasnya dalam undang-undang hukum pajak itu sendiri, juga sebagai sumber yang menerangkan tentang mana dan siapa subjek maupun objek yang perlu dan tidak perlu dijadikan sumber pemungutan pajak yang berfungsi untuk meningkatkan potensi pajak di negara ini. Adapun laporan pajak terutang ini berfungsi sebagai acuan dalam pembagian beban pajak kepada rakyat yang didasarkan pada kepentingan masing-masing orang.

Menurut Pasal 1 ayat (10) UndangUndang Nomor 16 Tahun 2009 disebutkan bahwa pajak yang terutang adalah pajak yang harus dibayar pada suatu saat, dalam Masa Pajak, dalam Tahun Pajak, atau dalam Bagian Tahun Pajak sesuai dengan ketentuan peraturan perundang- undangan perpajakan. Mengetahui penentuan saat terutang pajak Pengusaha Kena Pajak dalam melaksanakan kewajiban membayar pajaknya adalah sangat penting. Tanpa mengetahui saat pajak terutang, tidak mungkin dapat ditentukan kapan Pengusaha Kena Pajak harus memenuhi kewajiban pelunasan utang pajaknya.

Penentuan saat pajak terutang sangat erat kaitannya dengan penentuan saat timbulnya utang pajak. Pemungutan Pajak Pertambahan Nilai dan Pajak Penjualan atas Barang Mewah menganut prinsip akrual, artinya terutangnya pajak terjadi pada saat penyerahan Barang Kena Pajak atau Jasa Kena Pajak, meskipun pembayaran atas penyerahan tersebut belum diterima atau belum sepenuhnya diterima pada saat impor Barang Kena Pajak.

Saat terutangnya pajak untuk transaksi yang dilakukan melalui E-Commerce tunduk pada ketentuan ini: ${ }^{21}$ Penyerahan Barang Kena Pajak, Impor Barang Kena Pajak, Penyerahan Jasa Kena Pajak, Pemanfaatan Barang Kena Pajak tidak berwujud dari luar Daerah Pabean. Dalam hal orang pribadi atau badan memanfaatkan Barang Kena Pajak tidak berwujud dari luar Daerah Pabean di dalam Daerah Pabean atau memanfaatkan

\section{Jasa Kena Pajak dari luar Daerah}

Pabean di dalam Daerah Pabean, terutangnya pajak terjadi pada saat orang pribadi atau badan tersebut mulai memanfaatkan Barang Kena Pajak tidak berwujud atau Jasa Kena Pajak tersebut di dalam Daerah Pabean.

Hal itu dihubungkan dengan kenyataan bahwa yang menyerahkan Barang Kena Pajak tidak berwujud atau Jasa Kena Pajak tersebut di luar Daerah Pabean sehingga tidak dapat dikukuhkan sebagai Pengusaha Kena Pajak. Karena itu, saat pajak terutang tidak lagi dikaitkan dengan saat penyerahan, tetapi dikaitkan dengan saat pemanfaatan, Pemanfaatan Jasa Kena Pajak dari luar Daerah Pabean, Ekspor Barang Kena Pajak berwujud, Ekspor Barang Kena Pajak tidak berwujud, Ekspor Jasa Kena Pajak.

Dalam hal pembayaran diterima sebelum penyerahan Barang Kena Pajak atau sebelum penyerahan Jasa Kena Pajak atau dalam hal pembayaran dilakukan sebelum dimulainya pemanfaatan Barang Kena Pajak tidak berwujud atau Jasa Kena Pajak dari luar Daerah Pabean, saat terutangnya pajak adalah pada saat pembayaran.

Pelaporan pajak dapat disampaikan ke Kantor Pelayanan Pajak (KPP) atau Kantor Pelayanan, Penyuluhan dan Konsultasi Pajak (KP2KP) di mana wajib pajak terdaftar. Surat Pemberitahuan (SPT) dapat dibedakan menjadi Surat Pemberitahuan Masa dan Surat Pemberitahuan Tahunan.22

Surat Pemberitahuan Masa adalah Surat Pemberitahuan yang digunakan untuk melakukan pelaporan atas pembayaran pajak pada masa tertentu (bulanan). Ada 9 (sembilan) jenis Surat Pemberitahuan Masa, meliputi Surat Pemberitahuan Masa untuk melaporkan pembayaran bulanan. Pajak Penghasilan Pasal 21, Pajak Penghasilan Pasal 22, Pajak Penghasilan Pasal 23, Pajak Penghasilan Pasal 25, Pajak Penghasilan Pasal 26, Pajak Penghasilan Pasal 4 ayat (2), Pajak Penghasilan Pasal 15, Pajak Pertambahan Nilai dan Pajak Penjualan atas Barang Mewah, Pemungutan Pajak Pertambahan Nilai.

Sedangkan yang dimaksud dengan 
Surat Pemberitahuan Tahunan adalah Surat Pemberitahuan yang digunakan untuk pelaporan tahunan. Ada 2 (dua) jenis Surat Pemberitahuan Tahunan, yaitu Surat Pemberitahuan Tahunan Pajak Penghasilan Wajib Pajak Badan, dan Surat Pemberitahuan Tahunan Wajib Pajak orang pribadi.

Saat ini khusus untuk Surat Pemberitahuan Masa Pajak Pertambahan Nilai sudah dapat disampaikan secara elektronik melalui aplikasi e-Filling. Penyampaian Surat Pemberitahuan Tahunan Pajak Penghasilan juga dapat dilakukan secara online melalui aplikasi e-SPT. Dasar Pengenaan Pajak (DPP) adalah sebagai berikut. $^{23}$

Harga jual, adalah nilai berupa uang, termasuk semua biaya yang diminta atau seharusnya diminta oleh penjual karena penyerahan Barang Kena Pajak, tidak termasuk Pajak Pertambahan Nilai yang dipungut menurut Undang-Undang Pajak Pertambahan Nilai dan potongan harga yang dicantumkan dalam Faktur Pajak.

Penggantian, adalah nilai berupa uang, termasuk semua biaya yang diminta atau seharusnya diminta oleh pengusaha karena penyerahan Jasa Kena Pajak, ekspor Jasa Kena Pajak, atau ekspor Barang Kena Pajak Tidak Berwujud, tetapi tidak termasuk Pajak Pertambahan Nilai yang dipungut menurut Undang-Undang Pajak Pertambahan Nilai dan potongan harga yang dicantumkan dalam Faktur Pajak atau nilai berupa uang yang dibayar atau seharusnya dibayar oleh Penerima Jasa karena pemanfaatan Jasa Kena Pajak dan/atau oleh penerima manfaat Barang Kena Pajak Tidak Berwujud karena pemanfaatan Barang Kena Pajak Tidak Berwujud dari luar Daerah Pabean di dalam Daerah Pabean.

Nilai Impor, adalah nilai berupa uang yang menjadi dasar perhitungan bea masuk ditambah pungutan berdasarkan ketentuan dalam peraturan perundang-undangan yang mengatur mengenai kepabean dan cukai untuk impor Barang Kena Pajak, tidak termasuk Pajak Pertambahan Nilai dan Pajak Penjualan atas Barang Mewah yang dipungut menurut Undang- Undang Pajak Pertambahan
Nilai. Nilai Ekspor, adalah nilai berupa uang, termasuk biaya yang diminta atau seharusnya diminta oleh eksportir.

Penerapan Dasar Pengenaan Pajak diatur dalam berbagai peraturan pelaksanaan undang- undang sebagai berikut. Untuk penyerahan atau penjualan Barang Kena Pajak, yang menjadi Dasar Pengenaan Pajak adalah jumlah harga jual, Untuk penyerahan Jasa Kena Pajak, yang menjadi Dasar Pengenaan Pajak adalah penggantian, Untuk impor yang menjadi Dasar Pengenaan Pajak adalah nilai impor, Untuk ekspor yang menjadi Dasar Pengenaan Pajak adalah nilai ekspor.

Batas Waktu Pembayaran Pajak diatur di dalam PPh Pasal 21, Dilunasi paling lambat tanggal 10 (sepuluh) bulan takwim berikutnya. Lapor paling lama tanggal 20 (dua puluh) bulan takwim berikutnya. Pajak Penghasilan Pasal 22, Bendahara, Dilunasi pada hari yang sama dengan pelaksanaan pembayaran atas penyerahan barang yang dibiayai dari belanja negara. Lapor paling lama 14 (empat belas) hari setelah bulan takwim berikutnya. Pajak Penghasilan Pasal 23/26, Dilunasi paling lambat tanggal 10 (sepuluh) bulan takwim berikutnya. Lapor paling lama tanggal 20 (dua puluh) bulan takwim berikutnya. Pajak Pertambahan Nilai dan Pajak Penjualan atas Barang Mewah, Dilunasi paling lambat tanggal 15 (lima belas) bulan takwim berikutnya. Lapor paling lama tanggal 20 (dua puluh) bulan takwim berikutnya.

Keterlambatan Pelaporan Pajak untuk Surat Pemberitahuan Masa Pajak Pertambahan Nilai dikenakan denda sebesar Rp 500.000.00 (lima ratus ribu rupiah) dan untuk Surat Pemberitahuan Masa lainnya dikenakan denda sebesar Rp 100.000.00 (seratus ribu rupiah) dan Surat Pemberitahuan Tahunan Pajak Penghasilan Badan dikenakan denda sebesar Rp 1.000.000.00 (satu juta rupiah).

Sesuai dengan Peraturan Menteri Keuangan Nomor 80-PMK.03/2010 tentang Penentuan Tanggal Jatuh Tempo Pembayaran dan Penyetoran Pajak, Penentuan Tempat Pembayaran Pajak, dan Tata Cara 
Pembayaran, Penyetoran, dan Pelaporan Pajak, serta Tata Cara Pengangsuran dan Penundaan Pembayaran Pajak, diatur mengenai Penyetoran dan Pelaporan Pajak, sebagai berikut. Pasal 2 ayat (13) Pajak Pertambahan Nilai yang terutang atas kegiatan membangun sendiri harus disetor oleh orang pribadi atau badan yang melakukan kegiatan membangun sendiri paling lama tanggal 15 (lima belas) bulan berikutnya setelah Masa Pajak berakhir.

Pelaporan Pajak Pertambahan Nilai Pasal 7 ayat (1A). Pengusaha Kena Pajak wajib melaporkan Pajak Pertambahan Nilai dan Pajak Penjualan atas Barang Mewah yang telah disetor sebagaimana dimaksud dalam Pasal 2 ayat (13) dan ayat (13A), serta Pasal (2A) dengan menggunakan Surat Pemberitahuan Masa Pajak Pertambahan Nilai ke Kantor Pelayanan Pajak tempat Pengusaha Kena Pajak dikukuhkan, paling lama akhir bulan berikutnya setelah Masa Pajak berakhir.

Adapun tarif dan pajak terutang tidak terlepas dari rasa keadilan, sebab keadilan dapat menciptakan keseimbangan social yang sangat penting untuk kesehajteraan masyarakat. Dalam penetapan tarif pajak harus berdasarkan pada prinsip-prinsip keadilan, dan juga kepastian. Dalam perhitungan pajak yang terutang digunakan tarif pajak.

Tarif pajak yang dimaksud adalah tarif untuk menghitung besarnya pajak terutang (pajak yang harus dibayar). Apabila melihat timbulnya utang pajak, bahwa utang pajak timbul karena Surat Keputusan Pajak, ajaran ini diterapkan pada official assessment system. Perbedaan ajaran materiil bahwa utang pajak timbul karena undang-undang. Ajaran ini diterapkan pada self assessment system.

Hapusnya utang pajak disebabkan antara lain24 adalah Pembayaran, Utang pajak yang melekat pada Wajib Pajak akan hapus karena pembayaran yang dilakukan ke Kas Negara. Kompensasi, Keputusan yang ditunjukkan kepada kompensasi utang pajak dengan tagihan seseorang diluar pajak tidak diperkenankan. Oleh karena itu kompensasi terjadi apabila Wajib Pajak mempunyai tagihan berupa kelebihan pembayaran pajak. Jumlah kelebihan pembayaran pajak yang diterima Wajib Pajak sebelumnya harus dikompensasikan dengan pajak-pajak lainnya yang terutang. Daluwarsa diartikan sebagai daluwarsa penagihan.

Hak untuk melakukan penagihan pajak, daluwarsa setelah lampau waktu sepuluh tahun terhitung sejak saat terutangnya pajak atau berakhirnya Masa Pajak, bagian tahun pajak atau tahun pajak yang bersangkutan. Hal ini untuk memberikan kepastian hukum kapan uang pajak tidak dapat ditagih lagi. Namun daluwarsa penagihan pajak tertangguh, antara lain, apabila diterbitkan Surat Teguran dan Surat Paksa. Pembebasan, Utang pajak tidak berakhir dalam arti yang semestinya tetapi karena ditiadakan. Pembebasan pada umumnya tidak diberikan terhadap pokok pajaknya, tetapi diberikan terhadap sanksi administrasinya. Penghapusan utang pajak ini sama sifatnya dengan pembebasan, tetapi diberikan karena keadaan keuangan Wajib Pajak.

Seperti yang telah disampaikan sebelumnya dalam Organisation for Economic Co- operation and Development (OECD) terdapat 28 jenis transaksi E-Commerce yang dilakukan secara online dan berpeluang dikenakan pajak salah satunya adalah Advertising/Banner Ads. Google Indonesia dalam hal ini melakukan transaksi $E$ Commerce yang dilakukan secara online yaitu Advertising/Banner Ads. Google Indonesia diklaim telah menghindari pajak (Tax Avoidance) oleh Direktorat Jenderal Pajak kepada Google Indonesia terkait dengan masalah pajak yang sekarang dihadapi oleh Google Indonesia. Direktorat Jenderal Pajak akan meningkatkan tahapan kearah investigasi karena Google Indonesia menolak untuk diperiksa. ${ }^{25}$ Google Indonesia dianggap menghindari pajak karena belum menjadi Badan Usaha Tetap (BUT), dengan kata lain Google Indonesia belum menjadi Wajib Pajak.

Selama ini Google hanya membuat kantor perwakilan di Indonesia, bukan kantor 
tetap. Oleh karena itu, transaksi bisnis Google yang terjadi di Indonesia tidak berpengaruh kepada peningkatan pendapatan negara. Padahal transaksi dalam periklanan (Advertising/Banner Ads) secara online yang dilakukan oleh Google pada tahun 2015 mencapai $\$ 850$ juta (Delapan ratus lima puluh juta) atau sekitar Rp 11.600.000.000.00 (Sebelas triliun enam ratus juta rupiah).

Menurut catatan Direktorat Jenderal Pajak, Google di Indonesia telah terdaftar sebagai badan hukum dalam negeri di Kantor Perwakilan Pajak (KPP) Tanah Abang III dengan status sebagai Penanaman Modal Asing (PMA) sejak 15 september 2011 dan merupakan dependent agent dari Google Asia Pacific Pte Ltd di Singapura. Dengan demikian, menurut Pasal 2 ayat huruf (n) Undang-Undang Pajak Penghasilan, Google seharusnya berstatus sebagai BUT, sehingga setiap pendapatan maupun penerimaan yang bersumber dari Indonesia berhak dikenakan pajak penghasilan.

Negara-negara Organisation for Economic Co-operation and Development (OECD) telah sepakat bahwa pemungutan pajak penghasilan atas transaksi E-Commerce yang memiliki Bentuk Usaha Tetap (BUT) akan menggunakan asas sumber, jika tidak memiliki Badan Usaha Tetap maka akan digunakan asas domisili.

Penjelasan Badan Usaha Tetap menurut Pasal 2 ayat (5) Undang-Undang Pajak Penghasilan yaitu, Bentuk usaha tetap adalah bentuk usaha yang dipergunakan oleh orang pribadi yang tidak bertempat tinggal di Indonesia, orang pribadi yang berada di Indonesia tidak lebih dari 183 (seratus delapan puluh tiga) hari dalam jangka waktu 12 (dua belas) bulan, dan badan yang tidak didirikan dan tidak bertempat kedudukan di Indonesia untuk menjalankan usaha atau melakukan kegiatan di Indonesia, yang dapat berupa Tempat kedudukan manajemen, Cabang perusahaan, Kantor perwakilan, Gedung kantor, Pabrik, Bengkel, Gudang, Ruang untuk promosi dan penjualan, Pertambangan dan penggalian sumber alam, Wilayah kerja pertambangan minyak dan gas bumi, Perikanan, peternakan, pertanian, perkebunan, atau kehutanan, Proyek konstruksi, instalasi, atau proyek perakitan, Pemberian jasa dalam bentuk apapun oleh pegawai atau orang lain, sepanjang dilakukan lebih dari 60 (enam puluh) hari dalam jangka waktu 12 (dua belas) bulan.

Orang atau badan yang bertindak selaku agen yang kedudukannya tidak bebas, Agen atau pegawai dari perusahaan asuransi yang tidak didirikan dan tidak bertempat kedudukan di Indonesia yang menerima p1remi asuransi atau menanggung resiko di Indonesia, Komputer, agen elektronik atau peralatan otomatis yang dimiliki, disewa, atau digunakan oleh penyelenggara transaksi elektronik untuk menjalankan kegiatan usaha melalui internet.

\section{KESIMPULAN}

Berdasarkan uraian yang telah dilakukan berdasarkan permasalahan dan pembahasan, maka dapat diambil kesimpulan sebagai berikut:

1. Peraturan perundang-undangan yang mengatur pajak E-Commerce terkait dengan penerbitan SE-62/PJ/203 belum dapat terlaksana secara efektif karena penerbitan SE- 62/PJ/2013 ini hanya menegaskan bahwa tidak ada perbedaan di dalam transaksi yang dilakukan dengan cara biasa maupun online.

2. Laporan pajak terutang atas transaksi yang dilakukan melalui E-Commerce masih kurang efektif terkait Peraturan Pemerintah No 31 Tahun 2012 tentang Pemberian dan Penghimpunan Data dan Informasi yang berkaitan dengan perpajakan belum dapat terlaksana dengan baik, dan kurangnya data yang dimiliki oleh Direktorat Jenderal Pajak sehingga tidak semua Wajib Pajak dapat melaporkan pajak terutangnya karena transaksi yang dilakukan secara $E$ Commerce ini bukan saja dilakukan di dalam Negara Indonesia. Sehingga harus jelas siapa subjek, objek dan Negara mana yang berhak untuk memberikan pajak atas transaksi yang dilakukan melalui $E$ Commerce. 


\section{SARAN}

1. Peraturan perundang-undangan dan SE62/PJ/2013 dapat lebih benar-benar dapat mempertimbangkan pengaruh kedepannya nanti, tentu saja hal ini dapat dilakukan oleh Direktorat Jenderal Pajak dalam mempertimbangkan regulasi perpajakannya atas transaksi E-Commerce, yaitu dengan bekerja sama dengan pihakpihak terkait, seperti APJII dan Departemen Komunikasi dan Informasi. Memperhatikan sistem pemungutan pajak yang efektif dan mempertimbangkan modernisasi sistem administrasi perpajakan.

2. Laporan pajak terutang yang dihasilkan dari transaksi atas E-Commerce ini dapat dilakukan dengan pendekatan harmonisasi dan konvergensi agar kepastian hukum dalam pelaporan pajak atas transaksi elektronik dapat terlaksana dengan sebaikbaiknya. Penetapan tarif pajak harus berdasarkan pada prinsip-prinsip keadilan dan juga kepastian hukum sehingga akan menjadi jelas objek dan subjek pajaknya.

\section{DAFTAR PUSTAKA}

\section{Buku}

Brotodihardjo, R. Santoso. (2003). Pengantar Ilmu Hukum Pajak. Bandung: Refika Aditama. Darwin. (2010). Pajak Daerah dan Retibusi Daerah. Bogor: Mitra Wacana Media. Devano, Sony, dan Rahayu, Siti. (2006). Perpajakan: Konsep Teori, dan Isu. Jakarta:Kencana.

Erly Suandy. (2005). Hukum Pajak. Jakarta: Salemba Empat.

Ismail, Tjip, dkk. (2013). Analisis dan Evaluasi Tentang Pajak Dan Retribusi Daerah. Jakarta: Badan Pembinaan Hukum Nasional Kementerian Hukum dan Hak Asasi Manusia RI.

Ismail, Tjip. (2007). Pengaturan Pajak Daerah Indonesia. Jakarta: Yellow Printing. Ismail,Tjip. (2017). Hukum Pajak dan Acara Perpajakan. Jakarta: Fakultas Hukum, Ilmu Sosial dan Ilmu Politik Universitas
Terbuka (FHISIP-UT). Ismail, Tjip. (2018). Potret Pajak Daerah di Indonesia. Jakarta: Kencana.

Ismail, Tjip. (tanpa tahun). Kumpulan Artikel Kuliah Hukum Pajak. Jakarta: Fakultas Hukum Universitas Indonesia.

Mardiasmo. (2004). Otonomi dan Manajemen Keuangan Daerah. Yogyakarta: Penerbit Andi. Markus, Muda. (2005). Perpajakan Indonesia. Jakarta: Gramedia Pustaka Utama. Narbuko, Cholid dan Ahmani, Abu. (1997). Metode Penelitian. Jakarta: Bumi Aksara.

Saidi, M. Djafar. (2007). Pembaharuan Hukum Pajak. Depok: Rajagrafindo Persada. Siahaan, Marihot P. (2005). Pajak Daerah dan Retribusi. Depok: Rajagrafindo Persada.

Simanjuntak, Timbul H., dan Mukhlis, Imam. (2012). Dimensi Ekonomi Perpajakan dalam Pembangunan Ekonomi. Depok: Penebar Swadaya Grup.

Soemitro, Rachmad. (1986). Asas dan Perpajakan 1. Bandung: Rafika Aditama. Sutedi, Adrian. (2008). Hukum Pajak dan Retribusi Daerah. Bogor: Ghalia Indonesia.

Syamsi, Ibnu. (1994). Dasar-Dasar

Kebijakan Keuangan Negara.

Jakarta: Rineka Cipta.

Widjaja, H.A.W. (1998). Percontohan Otonomi Daerah di Indonesia. Jakarta: Rineka Cipta. Widjaja, H.A.W. (2002). Otonomi Daerah dan Daerah Otonom. Depok: Raja Grafindo Persada.

Zed, Mestika. (2003). Metode Penelitian Kepustakaan. Jakarta: Yayasan Obor Indonesia.

\section{Jurnal/Makalah}

Alkasasbeh, Omar Mohammad Abad., et.al. (2018). "The Impact of Government Expenditures, Taxes On Economic Growth in Jordan". American Based Research Journal, 7 (12): 32- 38. 
Bird, Richard M. (2000). "Intergovernmental Relations: Universal Principles, Local Applications, International Studies Program". Working Paper 00-2 April 2000, Andrew Young School of Policy Studiest, Georgia State University, Georgia USA.

Chia, Siow Yue. (2013). "The ASEAN Economic Community: Progress, Challanges, and Prospect."Asian Development Bank Institute (ADBI) Working Paper, No. 440.

Ismail, Tjip. (2011). "Implentasi Pajak Daerah dan Retribusi Daerah di Era Otonomi Daerah." Jurnal MasalahMasalah Hukum, 40 (2): 256-262.

Mann, Arthur J. (2001). "Perpajakan Daerah: Praktek-praktek Intemasional yang Standar", makalah dalam seminar "Domestic Trade, Decentralization, and Globalization" yang diselenggarakan USAID-Partnership for Economic Growth di Jakarta, 3 April 2001.

Meilani, Hilma. (2019). "Hambatan Dalam Meningkatkan Investasi Asing Di Indonesia dan Solusinya." Info Singkat Bidang Ekonomi dan Kebijakan Publik Pusat Penelitian Badan Keahlian DPR RI, Vol. XI, No. 19/I/Puslit/Oktober/2019.

Naharto, Michelle Jane, dan Tjondro, Elisa. (2014). "Analisis Tujuan Pemungutan serta Pengertian Penghasilan menurut Perpajakan dan Persepuluhan Bagi Wajib Pajak Orang Pribadi." Tax \& Accounting Review, 4 (1): 280-293.

\section{Peraturan Perundang-undangan}

Undang Undang Dasar Negara Republik Indonesia Tahun 1945 UndangundangNomor 32 tahun 2004 tentang Pemerintahan Daerah

Undang-undang Nomor 33 tahun 2004 tentang Perimbangan Keuangan antara Pemerintah Pusat dan Pemerintah Daerah

Undang-undang No. 28 tahun 2009 tentang Pajak Daerah dan Retribusi Daerah Undang-undang Nomor 12 Tahun

2011 tentang Pembentukan Peraturan Perundang-undangan

Undang-undang Nomor 23 tahun 2014 tentang PemerintahanDaerah Rancangan Undang- undang tentang Ketentuan dan Fasilitas Perpajakan Untuk Penguatan Perekonomian

Peraturan Pemerintah Nomor 143 Tahun 2000 jo. Peraturan Pemerintah Nomor 24 Tahun 2002 tentang Pelaksanaan Undang-undang Nomor 8 Tahun 1983 tentang Pajak Pertambahan Nilai Barang dan Jasa dan Pajak Penjualan atas Barang Mewah sebagaimana telah beberapa kali diubah terakhir dengan Undangundang Nomor 18 Tahun 2000.

Peraturan Pemerintah Nomor 144 Tahun 2000 tentang Jenis Barang dan Jasa Yang Tidak Dikenakan Pajak Pertambahan Nilai.

Peraturan Pemerintah Nomor 145 Tahun 2000 tentang Kelompok Barang Kena Pajak yang Tergolong Mewah yang Dikenakan Pajak Penjualan atas Barang Mewah sebagaimana telah beberapa kali diubah terakhir dengan Peraturan Pemerintah Nomor 12 Tahun 2006.

Peraturan Pemerintah Nomor 146 Tahun 2000 tentang Impor dan atau Penyerahan Barang Kena Pajak Tertentu dan atau Penyerahan Jasa Kena Pajak Tertentu yang Dibebaskan dari Pengenaan Pajak Pertambahan Nilai sebagaimana telah beberapa kali diubah terakhir dengan Peraturan Pemerintah Nomor 38 Tahun 2003.

Peraturan Pemerintah Nomor 12 Tahun 2001 tentang Impor dan atau Penyerahan Barang Kena Pajak Tertentu yang Bersifat Strategis yang Dibebaskan dari Pengenaan Pajak Pertambahan Nilai sebagaimana telah beberapa kali diubah terakhir dengan Peraturan Pemerintah Nomor 31 Tahun 2007.

Surat Edaran Nomor SE/62/PJ/2013 tentang Penegasan Ketentuan Perpajakan atas Transaksi E-Commerce. 


\section{Internet}

Susan Teltscher, Tariffs, Taxes and Electronic Commerce: Revenue Implications For Developing Countries. Policy Issues in International Trade and Commodities Study Series No.5, http://citeseerx.ist.psu.edu.

Torbjorn Fredriksson, E-Commerce and Development Key Trends and Issue, http://www.wto.org

Reska K Nistanto, Masalah

Pajak Yang Membelit

Googledi Indonesia, http://tekno.kompas.com/read/2016/0 9/19/09153207/masalah.pajak.yang. membelit.google.di.indo nesia 